\title{
LOS VALORES Y PRINCIPIOS CONSTITUCIONALES COMO LÍMITES A LA ACTUACIÓN DE LOS PODERES DEL ESTADO Y LA FUNCIÓN PÚBLICA
}

SUSANA DURO CARRIÓN

(C) UNED. Revista de Derecho Politico

N.o 111, mayo-agosto 2021 
SUMARIO

INTRODUCCIÓN. I. LEALTAD A LOS VALORES CONSTITUCIONALES Y LA ILICITUD DE LOS FINES CONTRARIOS. II. EL CARÁCTER INSTRUMENTAL DE LA ADMINISTRACIÓN PÚBLICA Y LOS LÍMITES EN SU ACTUACIÓN. III. EL JURAMENTO. LA ADHESIÓN INTERNA A LOS VALORES CONSTITUCIONALES EN EL ACCESO AL CARGO. IV. LA FIDELIDAD A LOS VALORES CONSTITUCIONALES COMO LIMITE AL EJERCICIO DE DERECHOS FUNDAMENTALES. V. CONCLUSIONES. 


\title{
LOS VALORES Y PRINCIPIOS CONSTITUCIONALES COMO LÍMITES A LA ACTUACIÓN DE LOS PODERES DEL ESTADO Y LA FUNCIÓN PÚBLICA
}

\author{
SUSANA DURO CARRIÓN ${ }^{1}$
}

\section{INTRODUCCIÓN}

Existe una cierta tensión con motivo del creciente proceso de politización de la Administración, dada su instrumentalización por las instancias propiamente políticas, en la bien conocida y progresiva tendencia de la alta función pública profesional a ocupar los más altos puestos del complejo político del Estado. En un Estado de Derecho, estas singulares circunstancias no pueden excusar la defensa de los valores democráticos y principios que, recogidos en nuestra Constitución, implicaron en su día tan importante pacto de consenso y tolerancia. Ese conjunto de valores identifica nuestro Estado constitucional, y no existe excusa que justifique la indiferencia ni hacia esos valores ni hacia los símbolos que nos identifican como nación. Los valores democráticos deben anteponerse a los cargos tanto políticos como funcionariales, cuestión que no siempre sucede.

Es por ello, que se convierte en preciso y urgente el establecimiento de medidas de sometimiento de la política al Derecho. Una Administración cuyo carácter es instrumental a favor de quienes ejercen legítimamente el poder, debe favorecer y promover los valores constitucionales y el respeto a nuestra Carta Magna, nuestra Ley Fundamental, atendiendo la función primordial de defensa constitucional que tanto la Administración como la función pública tienen encomendadas. Adicionalmente, es necesario dar su debida importancia a la ética, a la actitud y a la conducta de las personas que participan en la vida constitucional. En esta línea, se hace preciso y urgente una mayor disponibilidad de los dirigentes políticos y los gobernados para aceptar

1 Abogada, Doctora en Derecho Constitucional. Profesora Tutora de Derecho Constitucional y Tutora en el Master de Acceso a la Abogacía de UNED. Profesora Asociada en Universidad Rey Juan Carlos.Email: sduro@icam.es 
como moralmente imperativo el contenido de la Constitución ${ }^{2}$. Serían por todo ello, deseables mecanismos que eviten la transgresión y más allá, garanticen la defensa de nuestros valores constitucionales, tanto en la actuación de la Administración como de la función pública, y sin perjuicio de la necesaria represión que corresponda por parte de los Tribunales de aquellas conductas que pudieran considerarse ilegales.

Tampoco estaría de más fomentar y reforzar este concepto de deber de respeto a la Constitución en todos los ámbitos, pues imprescindible y esencial para un duradero mantenimiento de la forma de Estado, es una enseñanza adecuada de los valores constitucionales. Las más sagradas leyes producto de la unánime resolución de los ciudadanos no darán fruto mientras no nos preocupemos de que los individuos sean educados democráticamente en el espíritu constitucional ${ }^{3}$.

Vivimos en democracia y nuestros valores constitucionales son fruto de un pacto constitucional en el que el pueblo ha ejercido la titularidad de su soberanía, decidiendo sobre su propia existencia democrática como poder constituyente originario, indivisible e inalienable y en consecuencia, es difícil entender un Estado democrático indiferente que no proteja los valores que ese mismo pueblo ha elegido en el libre ejercicio de su soberanía popular.

Existen diferentes perspectivas en los diferentes países sobre este tema que nos ocupa como consecuencia principalmente de sus diversas trayectorias históricas. Distintos factores de diversa índole especialmente, y como es presumible, históricos y económicos, justifican las importantes diferencias existentes en la configuración de fondo y forma en los diversos sistemas. Los diversos sistemas jurídicos presentan también ciertas similitudes, en nuestro caso con el modelo alemán ${ }^{4}$, si bien en una perspectiva comparada con otros países, la Ley Fundamental alemana ha optado por una defensa de la Constitución con los instrumentos más completos del derecho comparado. De ahí las referencias en este trabajo al sistema alemán sin ningún ánimo de exponer una comparativa entre ambos modelos pues estos extremos desbordarían los límites marcados en esta obra, en la que lo que se pretende exponer únicamente, en su justa medida, es un alegato en favor de la defensa institucional de nuestros valores constitucionales, esencia de nuestro Estado de Derecho, y de nuestra nación como pueblo, sociedad, cultura y Estado.

2 Hesse, C., «Constitución y Derecho Constitucional» en Benda, E., Maihofer, W., Vogel, H., Hesse, K., Heyde, W., Manual de Derecho Constitucional. Editorial Marcial Pons. Madrid, 1996. Pág. 8.

3 Denninger, E., «Democracia Militante y defensa de la Constitución» en Benda, E., Maihofer, W., Vogel, H., Hesse, K., Heyde, W., Manual de Derecho Constitucional. Editorial Marcial Pons. Madrid, 1996. Pág. 450.

4 Torres Muro, I., «Estado aconfesional y libertad religiosa de los empleados públicos. Una visión desde España» en Elósegui Itxaso, M., La neutralidad del Estado y el papel de la religión en la esfera pública en Alemania, Actas, Zaragoza, 2012. Pág. 207 - 210. 


\section{LEALTAD A LOS VALORES CONSTITUCIONALES Y LA ILICITUD DE LOS FINES CONTRARIOS}

Es absolutamente lógico y admisible que en toda sociedad haya personas, grupos o programas políticos que aprecien más unos valores que otros. De hecho, nuestra Constitución, en su artículo 1.1 reconoce así el pluralismo político como valor superior del ordenamiento jurídico 5 .

En esta línea, toda Constitución democrática implica siempre la existencia de un pacto sobre los valores fundamentales con los que esa sociedad quiere vivir y a partir de ahí, desaparecido el poder constituyente, los poderes configurados como poderes constituidos y limitados se encuentran sometidos al Derecho y a la Constitución gracias al principio jurídico de supremacía constitucional. La supremacía constitucional es la traducción jurídica del principio de soberanía popular ${ }^{6}$. Toda democracia militante, como concepto más estricto de defensa de la Constitución, decidida a defenderse y capaz de defensa, protege sus principios de sujetos de los que no se deduce una voluntad constitucional ${ }^{7}$ y a diferencia de una concepción amplia de democracia, declarará ilícitas todas aquellas opciones políticas contrarias a los principios y valores constitucionales básicos, aunque los procedimientos que se empleen en su persecución sean $\operatorname{correctos}^{8}$, protegiendo de este modo, los principios constitucionales frente a una variedad de formas de ataque ${ }^{9}$. El Estado está legitimado para defenderse de aquellas ideas contrarias a los valores constitucionales, mientras que en una concepción más amplia de la defensa de la Constitución, en la democracia procedimental, tienen cabida todas las ideas y todos los programas políticos como legítimos siempre que utilicen métodos democráticos y aunque esas ideas y fines puedan ser contrarios a los valores básicos del constitucionalismo ${ }^{10}$, porque aquí el punto de

5 Torres del Moral, A., Principios de Derecho Constitucional español (Tomo I, Sistema de Fuentes, Sistema de los derechos). Servicio de Publicaciones de la Facultad de Derecho de la Universidad Complutense de Madrid. 2010, Madrid. Págs. 83 - 86.

6 Tajadura Tejada, J., La reforma constitucional: procedimientos y límites. Un estudio crítico del título $X$ de la Constitución de 1978. Editorial Marcial Pons. Madrid, 2018. Pág. 61 - 63.

7 Denninger, E., op. cit., pág. 454 - 455.

8 Álvarez Álvarez, L., «La defensa de la Constitución durante el periodo de entreguerras» en Historia Constitucional (revista electrónica), n. 7, 2006. Pág. 233.

9 Denninger, E., op. cit., pág. 454, 467 - 468.

10 Corcuera Atienza, J., Tajadura Tejada, J., Vírgala Foruria, E., La ilegalización de partidos políticos en las democracias occidentales., Dykinson, Madrid, 2008. Pág. 41-42. 
partida es la existencia de una voluntad constitucional ${ }^{11}$, tesis asumidas por nuestro Tribunal Constitucional en sus sentencias $18 / 81^{12}$ y 48/2003 $3^{13}$.

Tanto el Tribunal Constitucional como también el Tribunal Supremo ${ }^{14}$, niegan el carácter militante de nuestra democracia bajo el argumento de que la Constitución española permite expresamente la revisión total de su texto, sin existir cláusula alguna de intangibilidad y dado que, su artículo 168 expresamente recoge la posibilidad de una «revisión total» de su texto « ${ }^{15}$. En su interpretación del artículo 9.1 CE, manifiesta que también se respeta la Constitución en el supuesto extremo de que se pretenda su modificación por el cauce establecido en los artículos 166 y siguientes de la Norma Fundamental ${ }^{16}$, dando oportunidad por tanto, mediante la utilización de los procedimientos establecidos al efecto, a la creación de un nuevo y distinto texto constitucional ${ }^{17}$. De esta ausencia de límites materiales del artículo $168 \mathrm{CE}$, deducen ambos, la ausencia de una democracia militante, y dando un paso más, incluso la imposibilidad de controlar los fines de los partidos políticos ${ }^{18}$.

Ciertas opiniones doctrinales han extrapolado esta consideración asegurando que la ausencia de límites materiales de reforma desemboca en la ausencia de límites en las ideologías, sin que puedan por tanto, declararse ilícitas pretensiones cuyas consecuencias serán también ilícitas ${ }^{19}$. La Constitución establecería de esa forma, un orden de valores basado en un consenso extraordinariamente amplio, consenso que incluso podría llegar a desaparecer y ser sustituido por otro consenso sobre otros distintos valores, estableciéndose un nuevo orden no por la fuerza, sino mediante el Derecho ${ }^{20}$.

En una concepción sustantiva no procedimental de la democracia, el reconocimiento de unos límites materiales implícitos y universales, inherentes al propio

11 Denninger, E., op. cit., pág. 454.

12 Sentencia Tribunal Constitucional 18/1981, de 8 de junio. Sala Primera, FJ 2. (BOE núm. 143 de 16 de junio de 1981). («Por ello es necesario determinar su ámbito, teniendo en cuenta que la Constitución incorpora un sistema de valores cuya observancia requiere una interpretación finalista de la Norma Fundamental».)

13 Sentencia del Tribunal Constitucional 48/2003, de 12 de marzo (BOE núm. 63, de 14 de marzo de 2003) FJ 7.mo

14 STC 48/2003 (FJ 7) y STS 2133/2003, de 27 de marzo de 2003.

15 Sentencia del Tribunal Constitucional 48/2003, de 12 de marzo (BOE núm. 63, de 14 de marzo de 2003) FJ 7.

16 STC 101/1983, de 18 de noviembre, fundamento jurídico 3.

17 También la sentencia STC 122/1983, de 16 de diciembre de 1983, hace referencia a esta cuestión cuando en su fundamento jurídico 4 , interpreta la fidelidad a la Constitución como la ausencia de prohibición de perseguir ideales distintos a los constitucionales ni una renuncia a la reforma de la Constitución (o el Estatuto de Galicia).

18 Sentencia del Tribunal Constitucional 48/2003, de 12 de marzo (BOE núm. 63, de 14 de marzo de 2003) FJ 7. Esta misma idea es sostenida también posteriormente por el Tribunal Constitucional en su sentencia STC 5/2004, citada, FJ 17, negando el carácter militante de nuestra democracia.

19 Aragón Reyes, M., Estudios de Derecho Constitucional. Centro de Estudios Políticos y Constitucionales, Madrid, 1998. Págs. 199 - 201.

20 Aragón Reyes, M., Constitución, Democracia, y Control. Editorial Tecnos, Madrid, 1990. Págs. 48 $-51$. 
concepto de reforma efectuada por un poder constituido y limitado ${ }^{21}$, conduce a que la ideología incluso de los partidos políticos se encuentre limitada por los valores constitucionales y principios del ordenamiento jurídico, concretamente la soberanía popular, los derechos fundamentales, la separación de poderes, y a la supremacía constitucional con procedimiento específico de reforma y control de constitucionalidad de las normas. ${ }^{22}$ Adicionalmente, el hecho de que no exista en nuestra Constitución, como límite explícito al poder de reforma, una cláusula de intangibilidad ${ }^{23}$, como en el caso de la Ley Fundamental ${ }^{24}$, reflejo de su experiencia histórica ${ }^{25}$, no significa que no existan otros límites materiales expresos al poder de revisión. Los principios y valores esenciales del Estado constitucional diferencian entre reforma y destrucción de la Constitución. Los artículos 2 y 10 CE forman parte de ese núcleo irreformable de toda Constitución, y por ello, limitan ese significado de «revisión total» del artículo $168 \mathrm{CE}^{26}$. Si la reforma no tuviera límites materiales no podría distinguirse de la revolución y la Constitución quedará privada de todo componente axiológico y valorativo, e incurriría en un agnosticismo constitucional. ${ }^{27}$ El hecho de que nuestra Constitución permita su reforma total no significa que consienta cualquier cosa ni que admita cualquier método para lograrla ${ }^{28}$.

$\mathrm{Ni}$ es agnóstica nuestra democracia como forma de vida basada en valores regulados por el ordenamiento jurídico, ni es agnóstica la Constitución que le da forma

21 Tajadura Tejada, J., op. cit., pág. 65 - 66 y 151.

22 Corcuera Atienza, J., Tajadura Tejada, J., Vírgala Foruria, E., op. cit., pág. 33 - 45.

23 De acuerdo con Tajadura Tejada, prohibiciones expresas de reformar ciertas decisiones constitucionales básicas, quedando excluidas determinadas normas del ámbito del poder de revisión. Tajadura Tejada, J., op. cit., pág. 68.

24 La Ley Fundamental, cuya cláusula de intangibilidad es la más completa, sí reconoce la peculiaridad del poder de reforma de la Constitución frente al poder legislativo. El artículo 79.3 de la Constitución alemana establece la inadmisibilidad de toda modificación de la Ley Fundamental que afecte a la división de la federación en Länder, al principio de cooperación de los Länder en la legislación, o a los principios consignados en los artículos 1 y 20 relativos a la dignidad de la persona, y al Estado de Derecho y los derechos fundamentales, respectivamente.

25 Siguiendo a Stern K., Derecho del Estado de la República Federal Alemana. Centro de Estudios Constitucionales. Bilbao, 1987. Pág. 330 - 333, en Weimar, se admitía toda reforma de la Constitución si se respetaban las formas de procedimiento del artículo 76.1, siendo posible incluso la supresión total de la Constitución. La experiencia histórica vivida y la preocupación por esta cuestión se refleja en La Ley Fundamental, en su unidad textual incondicionada (artículo 79.1, 81.4, 115e.2, 19.1 LFB), en la garantía de inmodificabilidad de su núcleo material (artículo 79.3 LFB), en la supresión de las mayorías plebiscitarias, y en el incremento a una mayoría superior a dos tercios de los miembros de derecho del Bundestag y Bundesrat (artículo 79.2 y 121 LFB), respecto a la establecida para la ley ordinaria (esto es, mayoría simple de los votos emitidos, artículo 42.2 LFB), y si bien adicionalmente, el Bundesrat también ha de consentir en la ley de reforma constitucional con mayoría de dos tercios (artículo 79.2 LFB: «Una ley de este carácter requiere la aprobación de una mayoría de dos tercios de los miembros del Bundestag $y$ de dos tercios de los votos del Bundesrat».)

26 Tajadura Tejada, J., op. cit., pág. 68 y $141-150$.

27 Tajadura Tejada, J., ibidem pág. 31 - 33 y 61 - 64 y 137.

28 Morodo, R., y Murillo de la Cueva, P.L., El ordenamiento constitucional de los partidos políticos. Universidad Autónoma de México. México, 2001. Pág. 137 - 139.

N. ${ }^{\circ} 111$, mayo-agosto 2021, págs. 225-254 
jurídica. La Constitución propugna unos valores frente a los que los poderes públicos no pueden permanecer indiferentes cuando se intenta suprimirlos, y aquí late la idea de pacto inseparable de la de Constitución. La libertad, la justicia, la igualdad y el pluralismo político han de ser propugnados y defendidos por la función pública y las instituciones del Estado como valores superiores de la democracia, y ello necesariamente conduce a militar en ellos frente a quienes han decidido destruirlos. Porque el término "propugnar» del artículo 1.1 de nuestra Carta Magna equivale a defender y militar. En esta línea, toda democracia es militante, y debe serlo. Militante frente a los «enemigos» de su esencia, de esos valores que constituyen su propia ética y normas de convivencia, enemigos de la libertad que pretenden poner en peligro la propia democracia. En materia de valores, toda democracia que se precie debe ser militante y fuerte en su propia defensa, y no neutra, indigente. ${ }^{29}$ Cuando calificamos a una democracia como militante estamos aludiendo a formas específicas de protección identificables en cualquier democracia verdadera, aunque no en todos los casos sean las mismas, y por eso podemos hablar de distintos tipos de democracia militante, no necesariamente vinculados al modelo alemán. ${ }^{30}$

En Alemania, es en este concepto de defensa de la Constitución donde se sitúa el trasfondo tanto de la «democracia militante» del funcionario público como lealtad federal, desempeñando esta cuestión un decisivo protagonismo en el contexto de los principios democrático, federal y de derecho, desde la aprobación misma de la Ley Fundamental de Bonn de 1949. ${ }^{31}$

En esta misma línea y desde esta misma perspectiva, el Tribunal Constitucional se aleja de la distinción sujeción y lealtad constitucional como premisa de partida y en consecuencia, se aparta también de una concepción militante de nuestro ordenamiento jurídico. En su interpretación del artículo 9.1 de la Constitución, entiende un deber de lealtad contenido en la sujeción a la Constitución, y una fidelidad que se confunde con el deber de obediencia a la Constitución y al resto del ordenamiento jurídico. De este artículo 9.1 (los ciudadanos y los poderes públicos están sujetos a la Constitución y al resto del ordenamiento jurídico) se deriva que la sujeción a la Constitución, entendida como deber negativo de no actuar contra ella, se aplica a todos y que esta sujeción actúa como deber positivo de obrar con arreglo a la misma respecto a quienes son titulares de poderes públicos ${ }^{32}$. De este modo, el deber de acatamiento constitucional inherente al cargo, con independencia de que se exteriorice, «no supone necesariamente una adhesión ideológica ni una conformidad a su total conteni-

29 Torres del Moral, A., «Terrorismo y principio democrático». Revista de Derecho Político UNED núm. 78, mayo-diciembre 2010. Madrid., pág. 145 - 147 y 156.

30 Vidal, C. (2009), "Spain”, en Thiel, M. (Dir.), The 'Militant Democracy' Principle in Modern Democracies. Ashgate, Surrey, págs. 247-248.

31 Álvarez Álvarez, L., «La defensa de la Constitución durante el periodo de entreguerras» en Historia Constitucional (revista electrónica), n. 7, 2006. Pág. 231.

32 STC 122/1983, de 16 de diciembre de 1983, FJ 4. 
do... $»^{33}$. La similitud que el Tribunal Constitucional realiza entre lealtad y sujeción a la Constitución ${ }^{34}$ se manifiesta en ese comportamiento leal, unas veces basado en la abstención y no interferencia y otras veces en una conducta activa para facilitar las plenas competencias del Estado ${ }^{35}$, y por tanto, en palabras de nuestro Tribunal Constitucional, en nuestro ordenamiento jurídico no tiene cabida un modelo de «democracia militante» en el que se imponga, no ya el respeto, sino la adhesión positiva al ordenamiento y en primer lugar, a la Constitución ${ }^{36}$.

Especial trascendencia en este ámbito, posee este pronunciamiento del Tribunal Constitucional en su sentencia 48/2003 37 , como consecuencia de la interpretación por parte del Gobierno Vasco como democracia militante las referencias de la LO 6/2002 de partidos políticos a los valores constitucionales y los principios democráticos. Se remite la sentencia a su Exposición de Motivos en el sentido que «cualquier proyecto u objetivo se entiende compatible con la Constitución siempre y cuando no se defienda mediante una actividad que vulnere los principios democráticos o los derechos fundamentales de los ciudadanos ${ }^{38}$, considerando que la ley, diferenciando entre actividades y fines del partido político, no impone límites a sus fines, idearios o programas políticos, sino únicamente a su actividad ${ }^{39}$, y que para llegar a la suspensión o ilegalización de esos partidos, la ley solo requiere la reiteración de ciertas conductas tipificadas $^{40}$. Ni el legislador en el artículo 9 de la LO 6/2002, ni el artículo 6 CE, establecen limitaciones ni deber de respeto a los valores constitucionales, y los únicos fines vetados son aquellos que incurren en el ilícito penal. Sólo las conductas y actividades partidistas que vulneran las exigencias del artículo 6 de la Constitución española se constituyen como causas de ilegalización del partido, y mientras esos valores o programas políticos inconstitucionales no se exterioricen con conductas graves y reiteradas, el partido no incurriría en causa de disolución.

Podemos decir por tanto, que la ley española es sumamente suave y condescendiente con los «enemigos de la libertad ${ }^{41}$, si como inciso tomamos como referencia

33 STC 101/1983, de 18 de noviembre, FJ 3.

34 STC 122/1983, de 16 de diciembre de 1983, FJ 5.

35 Álvarez Álvarez, L., La lealtad constitucional en la Constitución Española de 1978, Centro de Estudios Políticos y constitucionales, 2008, Madrid. Págs. XVIII y XIX.

36 Sentencia del Tribunal Constitucional 48/2003, de 12 de marzo (BOE núm. 63, de 14 de marzo de 2003) FJ 7. Esta misma idea es sostenida también posteriormente por el Tribunal Constitucional en su sentencia STC 5/2004, citada, FJ 17, negando el carácter militante de nuestra democracia.

37 Sentencia del Tribunal Constitucional 48/2003, de 12 de marzo (BOE núm. 63, de 14 de marzo de 2003).

38 Ley Orgánica 6/2002, de 27 de junio, de partidos políticos, Exposición de Motivos.

39 Tajadura Tejada, J., Partidos políticos y Constitución. Un estudio de la lo 6/2002, de 27 junio, de Partidos Políticos, y de la STC 48/2003, de 12 marzo. Editorial Aranzadi. Thomson, Civitas. 2004. Madrid. Pág. $81-82$.

40 Torres del Moral, A., «La inconstitucionalidad de los partidos políticos. A propósito de la Ley Orgánica 6/2002 de partidos políticos». Revista de Derecho Político, UNED, núm. 60. Madrid, 2004. Pág. $54-55,60-61,66$ y 68 .

${ }^{41}$ Torres del Moral, A., ibídem, pág. 58.

(C) UNED. Revista de Derecho Politico

N. ${ }^{\circ} 111$, mayo-agosto 2021, págs. 225-254 
el artículo 21 de la Constitución alemana ${ }^{42}$ que establece la inconstitucionalidad y la posible disolución para aquellos partidos que pretendan, y recalco «pretendan», desvirtuar el orden constitucional ${ }^{43}$.

A pesar de ello, esta distinción entre control de la actividad de los partidos y control de su ideología no es admitida por los críticos de la ley, quienes consideran que desde una perspectiva práctica, a través del control de las actividades, la ley controla indirectamente también los fines y la ideología de los partidos ${ }^{44}$.

A esta consideración cabría alegar que la exigencia del artículo 9 CE sobre el respeto a los valores y principios democráticos conduce inevitablemente a formas de control de la constitucionalidad de los fines de los partidos políticos, si bien el Código Penal pueda constituirse como barrera principal en este control de los partidos ${ }^{45}$, y además de hecho, no existe vicio de inconstitucionalidad en el control de las actividades como control ideológico indirecto a través de la prohibición de esas conductas finalistas ${ }^{46}$ y ello, aunque como manifiesta la sentencia, los únicos fines explícitamente vetados sean aquéllos que incurren en el ilícito penal ${ }^{47}$, y la disolución de los partidos, como la de las asociaciones, sólo podría traer causa de su ilicitud penal (art. $515 \mathrm{CP})^{48}$.

Enemigos de la Constitución son quienes persiguen fines contrarios a ella, y vislumbrando la lealtad constitucional desde la perspectiva de norma de defensa del Estado, nos conduce inevitablemente a la ilegalización de los enemigos de la Constitución, es decir a quienes persiguen fines contrarios a los principios estructurales. Por ello, esta lealtad constitucional conduce a la prohibición de aquellas actividades que pongan en peligro el orden democrático liberal constituido por aquellos principios estructurales del Estado social y democrático de Derecho, y esto es lo que precisamente sucede en el artículo 21,2 GG, que considera inconstitucionales los partidos políticos cuya sola intención implique la lesión del orden democrático liberal.

$\mathrm{Y}$ es que ni la norma de lealtad constitucional se deduce del artículo 9.1 CE, ni tampoco equivale a sujeción constitucional. Además de articular una vinculación a la Constitución más intensa que la norma de sujeción a la Constitución y al ordena-

42 Artículo 21.2 Ley Fundamental de Bonn. Ley para la República Federal de Alemania (Grundgesetz für die Bundesrepublik Deutschland), de 22 de mayo de 1949. ( Los partidos que por sus fines o por el comportamiento de sus adherentes tiendan a desvirtuar o eliminar el régimen fundamental de libertad y democracia, o a poner en peligro la existencia de la República Federal de Alemania, son inconstitucionales.»)

43 Denninger, E., op. cit., pág. 460. En el ámbito de la democracia militante, y en un sentido estricto de defensa constitucional, de acuerdo con este artículo 21.2 GG, en la defensa del orden fundamental libre y democrático, no se declara un partido contrario a la Constitución, ni por lo tanto, queda prohibido, por el hecho de que atente contra ciertas normas o instituciones por medios legales, sino simplemente «cuando se proponga atentar contra los valores superiores del Estado democrático».

44 Corcuera Atienza, J., Tajadura Tejada, J., Vírgala Foruria, E., op. cit., pág. 34 - 35.

45 Morodo, R., y Murillo de la Cueva, P.L., op. cit., pág. 137.

46 Corcuera Atienza, J., Tajadura Tejada, J., Vírgala Foruria, E., op. cit., pág. 34 - 35.

47 Ley Orgánica 6/2002, de 27 de junio, de partidos políticos, Exposición de Motivos, y STC 48/2003, de 12 de marzo, FJ 7. (BOE núm. 63, de 14 de marzo de 2003).

48 STC 48/2003, de 12 de marzo, FJ 4. (BOE núm. 63, de 14 de marzo de 2003) 
miento jurídico, mientras la norma de lealtad tiene como objetivo el contenido nuclear de los principios estructurales y proyecta su eficacia sobre todo el ordenamiento jurídico, la vulneración de la sujeción se produce con la transgresión de cualquier norma jurídica. ${ }^{49}$

Nuestra Carta Magna abandona la histórica concepción de lealtad vinculada a las relaciones de sujeción especial en que la relación entre funcionario y Estado se establecía sobre una lealtad que podría conllevar incluso la anulación de derechos fundamentales. Nuestra Constitución da paso a un status funcionarial específico y en el que se presume un mayor grado de lealtad constitucional. Y aunque no ha introducido la clausula de lealtad o fidelidad como ha sucedido en muchas Constituciones, de su artículo 103.1 cabe deducir un deber implícito de mayor fidelidad a la Constitución, concretamente un deber de omisión de conductas contrarias y deber de neutralidad con una observación escrupulosa del del deber de obediencia a la Constitución. De este modo, podría interpretarse que nuestra Constitución establece un modelo de democracia pluralista, no militante, en que no existe un mecanismo expreso de control de fidelidad, lealtad o adhesión. Estamos ante una relación jurídica personal ${ }^{50}$ en el sentido de relación especial del Derecho administrativo y en la que la Constitución confía ciertas tareas a la función pública ${ }^{51}$.

No obstante, en este tema existen multitud de cuestiones más específicas tratadas por la doctrina administrativista, cuyo planteamiento desbordaría los límites marcados en esta obra.

\section{EL CARÁCTER INSTRUMENTAL DE LA ADMINISTRACIÓN PÚBLICA Y LOS LÍMITES EN SU ACTUACIÓN}

Por lo hasta aquí expuesto, es esencial el papel del ordenamiento jurídico que demandando un proceso ordenado, una organización y una conciliación de voluntades en cuanto a los valores fundamentales con los que la sociedad quiere vivir, reconoce la Constitución en el cumplimiento de esta función, además de otorgar las competencias estatales a los órganos del Estado en los que confía la cooperación, responsabilidad y limitación del poder, convirtiéndose en el orden jurídico del Estado y de la comunidad ${ }^{52}$.

49 Álvarez Álvarez, L., La lealtad constitucional en la Constitución Española de 1978, Centro de Estudios Políticos y constitucionales, 2008, Madrid. Pág. 14 - 18, 53 - 56, 72

50 Stern, K., op. cit., pág. 376, 385, 616-618 y 632-644.

51 Salguero Salguero, M., «Socialización política y lealtad a la Constitución» en Revista de Estudios Políticos (Nueva Época), núm. 97. Julio-Septiembre 1997. Págs. 327 - 331. Sobre esta cuestión puede además consultarse entre otros, Embid Irujo, A., La fidelidad de los funcionarios a la Constitución. Un estudio de los derechos alemán y español. Instituto Nacional de Administración Pública. 1987. Madrid. García Macho, R., Relaciones de especial sujeción en la Constitución española, Tecnos, Madrid, 1992; López Benítez, M., Naturaleza y presupuestos constitucionales de las relaciones especiales de sujeción, Civitas, Madrid, 1994.

52 Hesse, C., op. cit., pág. 3 - 4.

N. ${ }^{\circ} 111$, mayo-agosto 2021, págs. 225-254 
De ahí que en los regímenes democráticos, el carácter instrumental de la administración y la función pública adquieran especial importancia en este punto. Se encuentran al servicio de quienes ejercen legítimamente el poder, por ser elegidos por el pueblo a través de unas elecciones en las que éste elige un determinado partido y programa político y entrega a ese nuevo gobierno el poder de decisión y la confianza en la realización de ese programa político que por tanto, no debería modificar ${ }^{53}$. Buscando la seguridad de los derechos, la autoridad elegida ejerce entonces el poder, pero sin que deba olvidar que está al servicio de esos derechos y no al contrario ${ }^{54}$. En el Estado constitucional, todos los poderes son constituidos y limitados por la propia Constitución y ningún poder del Estado puede configurarse como ilimitado 55 . Deviene necesario en este sentido, un proceso de «juridificación» en cuanto sometimiento de la política al derecho ${ }^{56}$, a la Constitución, a los principios y valores constitucionales y al ordenamiento jurídico.

En determinadas ocasiones, podría confundirse la democracia con el mero acceso al poder y al gobierno y en estas circunstancias sería evidente la ausencia de valores ${ }^{57}$. En esta línea, y siguiendo a Stern, el deterioro del Estado y sus instituciones se produce tanto «desde abajo» como «desde arriba» mediante la infiltración en cargos públicos y un «vaciado» del orden constitucional «desde dentro». Es por ello, que la defensa de la Constitución, enfocada frente a todo tipo de ataques, a los bienes constitucionales protegidos, ha de involucrar a todo el Estado constitucional ${ }^{58}$ y a todas sus instituciones y además, evitando tanto las apreciaciones intencionadamente erróneas de estas situaciones como la falta de medidas.

La protección de la Constitución por la función pública requiere en consecuencia, una vertiente institucional y una vertiente personal ${ }^{59}$. Nuestra Carta Magna exige tanto una actuación objetiva de la Administración como la imparcialidad del empleado público en el ejercicio de sus funciones (art. 103.1 y 3 CE).

La Constitución española, en su artículo 103.1, establece la objetividad como rasgo fundamental de la administración pública y como norma de conducta para que sus actuaciones sean justas y ajenas a influencias de intereses partidistas. La actuación objetiva es algo intrínseco a la idea de servicio si bien en el caso de la Administración,

53 Álvarez Álvarez, J., «Neutralidad política y carrera administrativa de los funcionarios públicos» en Revista de Documentación Administrativa 1987, núms. 210 - 211. Pág. 71 - 74.

54 Torres del Moral, A., «Terrorismo y principio democrático». Revista de Derecho Político UNED núm. 78, mayo-diciembre 2010. Madrid. Pág. 105 - 106.

55 Tajadura Tejada, J., La reforma constitucional: procedimientos y límites. Un estudio crítico del título X de la Constitución de 1978. Editorial Marcial Pons. Madrid, 2018. Pág. 61

56 Tajadura Tejada, J., Partidos políticos y Constitución. Un estudio de la lo 6/2002, de 27 junio, de Partidos Políticos, y de la STC 48/2003, de 12 marzo. Editorial Aranzadi. Thomson, Civitas. 2004. Madrid. Pág. 37 - 39

57 Sanz Moreno, J.A., «Democracia finalista y defensa de la constitución española» en Revista de derecho la UNED, Núm. 10, 2012. Pág. 621

58 Stern, K., op. cit., pág. 384 - 385.

59 Stern, K., ibídem, pág. $375-376$. 
al estar orientada esa prestación de servicios públicos a «los intereses generales», el concepto queda reforzado como cuestión vinculada al principio de la neutralidad política de la Administración de modo que ambos términos, objetividad y neutralidad, están estrechamente relacionados pudiendo llegar a utilizarse de forma indistinta. ${ }^{60}$ Nuestro Tribunal Constitucional, refiriéndose expresamente a todas las instituciones públicas (aunque mencione también a los centros docentes), extiende la aplicación del principio de neutralidad del Estado a todos los ámbitos ${ }^{61}$ como requisito necesario para la existencia de pluralismo político ${ }^{62}$, valor superior de nuestro ordenamiento jurídico, y con el fin de asegurar el equilibrio de una administración estable frente a las fuerzas políticas, siendo además deseable que las tareas soberanas puedan ser confiadas a funcionarios con una relación de estrecha lealtad y servicio con el titular del servicio público ${ }^{63}$.

Sin embargo, ni la objetividad de la Administración y del Estado frente a las convicciones de los ciudadanos como garantía del pluralismo, ni la imparcialidad de la función pública debe interpretarse de ningún modo, como ausencia de valores, convirtiéndose en necesario para su protección un sistema de «defensa militante». ${ }^{64}$

En nuestro ordenamiento, la defensa de la Constitución es objeto de un amplio conjunto de preceptos entre los que en líneas generales, cabe mencionar aquellos que regulan la defensa constitucional por los poderes públicos, desempeñando en este punto el artículo 9.1 una labor fundamental. ${ }^{65}$ En la misma línea, otros preceptos de nuestro ordenamiento jurídico y entre otros, el artículo 26 de la Ley de transparencia, acceso a la información pública y buen gobierno ${ }^{66}$ establecen la dedicación al servicio público conforme al nuestra Carta Magna y promoviendo siempre el respeto a los derechos fundamentales y a las libertades públicas.

De este modo, la neutralidad estatal y de los poderes públicos no es incompatible por tanto, con esa labor de impulso del ideario constitucional en el que se insertan los valores superiores de los artículos 1.1 y 10.1. Todo lo contrario. Los poderes públicos, de acuerdo con la vertiente positiva de la neutralidad que les caracteriza, se hallan comprometidos a un deber de protección y promoción del pluralismo y la convivencia

60 Arias Martínez, M. A., «El principio de objetividad en el empleo público II: La objetividad como deber de los empleados públicos». Revista Documentación Administrativa. n 289, enero-abril 2011. Pág. 184

${ }^{61}$ Sentencia del Tribunal Constitucional 5/1981, de 13 febrero, fundamento jurídico 9 (BOE núm. 47, de 24 de febrero de 1981).

62 Blat Jimeno, Francisco R., Relaciones laborales en empresas ideológicas, Ministerio de Trabajo y Seguridad Social, Madrid, 1986. Pág. 75 -77.

63 Stern, K., op. cit., pág. 616 - 618.

64 Suárez Pertierra, G., «Laicidad y cooperación como bases del modelo español: un intento de interpretación integral (y una nueva plataforma de consenso)» en Revista Española de Derecho Constitucional núm. 92, mayo agosto 2011. Pág. 60.

65 Embid Irujo, A., La fidelidad de los funcionarios a la Constitución. Un estudio de los derechos alemán y español. Instituto Nacional de Administración Pública. 1987. Madrid. Págs. 125- 126.

${ }^{66}$ Ley 19/2013, de 9 de diciembre, de transparencia, acceso a la información pública y buen gobierno. BOE núm. 295, de 10 de diciembre de 2013. 
pacífica configurada por el sistema de valores democráticos ${ }^{67}$. La neutralidad positiva del Estado y esa labor de «impulso» encomiendan a los poderes públicos y a la Administración una labor activa en el fomento y desarrollo del ideario constitucional, de los valores constitucionales. El Estado constitucional español se identifica con un conjunto de valores que definen su identidad y en este sentido, frente a esos valores constitucionales, el Estado no puede ser indiferente ${ }^{68}$ sino que ha de promover todas aquellas condiciones necesarias para que esos valores constitucionales sean efectivos y reales de acuerdo con el artículo 9.2 de nuestra Carta Magna.

Otros preceptos de nuestro ordenamiento jurídico, como el artículo 55 de la Ley del Parlamento de Cataluña ${ }^{69}$ sobre transparencia, acceso a la información pública y buen gobierno, establecen expresamente un Código para los Altos Cargos del Estado en el que expresamente establece como principio ético y regla de conducta «El respeto a la Constitución, el Estatuto de autonomía y el principio de legalidad», excluyendo expresamente el uso de las instituciones para atacar la Constitución o los valores constitucionales.

La defensa de la Constitución ha de conducir por tanto, a la declaración de ilícitos para todos aquellos fines contrarios a las normas jurídico-positivas, aun cuando los procedimientos utilizados en su persecución sean democráticos, de modo que su función y objetivo es garantizar la eficacia de la Constitución como norma suprema del ordenamiento y responder ante cualquier infracción, reprimiendo aquellas actividades infractoras de la misma. ${ }^{70}$

\section{LA ADHESIÓN INTERNA A LOS VALORES CONSTITUCIONALES EN EL ACCESO AL CARGO. EL JURAMENTO}

En la democracia militante alemana la diversidad de posibilidades de defensa de la Constitución, podría llevar incluso a plantear la posibilidad de pérdida de los derechos fundamentales o la posible prohibición de un partido, si bien estas medidas no destaquen en la experiencia práctica ${ }^{71}$.

En el acceso a la condición de funcionario, la redacción del artículo 33 párr. 3 de la Ley Fundamental («El disfrute de los derechos civiles y cívicos, la admisión a los

67 Valero Heredia, A., Libertad de conciencia, Neutralidad del Estado y Principio de laicidad (Un estudio constitucional comparado), Ministerio de Justicia, Secretaría General Técnica, Madrid, 2008, págs. 111 - 117.

68 Suárez Pertierra, G., op. cit., pág. 60.

${ }_{69}$ Ley 19/2014, de 29 de diciembre, de transparencia, acceso a la información pública y buen gobierno. Comunidad Autónoma de Cataluña. DOGC núm. 6780, de 31 de diciembre de 2014. BOE núm. 18, de 21 de enero de 2015.

70 Álvarez Álvarez, L., «La defensa de la Constitución durante el periodo de entreguerras» en Historia Constitucional (revista electrónica), n. 7, 2006. Pág. 229 - 231.

71 Denninger, E., op. cit., pág. 454, 467 - 468. 
cargos públicos, así como los derechos adquiridos en el servicio público son independientes de la confesión religiosa. Nadie podrá ser discriminado a causa de su pertenencia o no pertenencia a una confesión o ideología.») prohíbe la discriminación por motivos religiosos tanto en el acceso a los servicios públicos, como para los empleados de los mismos. Podría plantearse la existencia de un conflicto entre la prohibición de discriminación que recoge este artículo con la redacción del párr. 2 del mismo artículo 33 LF («Todos los alemanes tienen igual acceso a cualquier cargo público según su idoneidad, su capacidad y su rendimiento profesional») dado que el término «aptitud» reviste unas connotaciones muy específicas en cuanto a cualidades personales y de carácter $^{72}$. El Tribunal Constitucional alemán se pronunció expresamente sobre este tema en su sentencia de 22 de mayo de $1975^{73}$ manifestando que el artículo 3 párrafo 3 de la Ley Fundamental ( Nadie podrá ser perjudicado ni favorecido a causa de... sus creencias y sus concepciones religiosas o políticas») obedece al artículo 3 párrafo 1 («Todas las personas son iguales ante la ley») de la misma LFB. Como manifiesta la propia sentencia, la prohibición se refiere por tanto, a considerar las creencias políticas como punto de partida para discriminar o conceder privilegios y esta cuestión no relativizaría el deber de lealtad del funcionario público, que se encuentra enraizado en el ejercicio de la función pública.

Ante la imperante necesidad para el Estado de previsión y garantía del cumplimiento por el futuro funcionario del deber de defensa de la Constitución y del Estado y actuación en términos favorables al ordenamiento jurídico, la valoración de su personalidad en el acceso a la función pública alemana no se considera como una vulneración de sus derechos fundamentales ${ }^{74}$ encontrándonos por tanto, ante criterios de valoración ideológica en el acceso a puestos en la función pública.

A ello se debe que la propia sentencia continúe diciendo que no puede realizarse una abstracción absoluta de la prohibición del artículo 3 párrafo 3 de la Ley Fundamental pues existen ciertos límites que justifican que la prohibición de este artículo opere solo para los perjuicios o favorecimientos intencionales. ${ }^{75}$

Merece la pena destacar como fundamento último de esta regulación el propósito del legislador. Como manifiesta el Tribunal Constitucional alemán, una disposición constitucional no puede ser interpretada en forma aislada, sino que debe interpretarse dentro del contexto general de la Constitución ${ }^{76}$ y en ese contexto normativo, como objetivo legislativo, se excluye toda posibilidad de que la misma Constitución ofrezca entregar ese Estado (con ayuda del artículo 3, párrafo 3 Ley Fundamental) a los ene-

72 Frings, D., «La libertad de culto de los empleados de la Administración Pública conforme al art. 33, parr.3 de la Ley Fundamental con respecto a la neutralidad del Estado», en Elósegui Itxaso, M., La neutralidad del Estado y el papel de la religión en la esfera pública en Alemania, Actas, Zaragoza, 2012, pág. 176.

73 BVerfGE 39, 334, Segunda Sala, 22 de mayo de 1975. BvL 13/73.

74 Blat Jimeno, Francisco R., op. cit., pág. 75-77.

75 BVerfGE 39, 334, Segunda Sala, 22 de mayo de 1975. BvL 13/73.

76 BVerfGE 19, 206 [220]; 30, 1 [19]; 33, 23 [29]. 
migos de la Ley Fundamental ${ }^{77}$ institucionalizándose el Berufsverbot, o procedimiento que impide el acceso o separa de la función pública a quien no ofrece garantías de una futura defensa del ordenamiento democrático liberal, cuyo principal fundamento en la configuración de esta institución son los artículos 33.4 («El ejercicio de facultades de soberanía será confiado, como regla general y con carácter permanente, a funcionarios del servicio público sujetos a una relación de servicio y lealtad, bajo un régimen de Derecho público.») y 33.5 de la LFB («El estatuto legal del servicio público debe ser regulado y desarrollado teniendo en cuenta los principios tradicionales del régimen de funcionarios de carrera») así como la Ley Federal sobre funcionarios públicos de 12 de julio de 1971.

Ante el control sobre la ideología por parte del Estado admitido por el propio Tribunal Constitucional, los citados artículos de la Constitución alemana constituyen el fundamento constitucional por el que el deber de fidelidad se configura tanto en condición necesaria en la relación funcionarial alemana como en requisito para el acceso a la función pública, presupuestos acordes con la legislación de $1972^{78}$.

No podemos dejar de señalar en este punto, cómo el Tribunal Constitucional alemán en la sentencia de 24 de septiembre de 2003 , relativa al velo islámico, fundamenta la sentencia en la aplicación del artículo 32.2 de la LFB, artículo que garantiza el acceso a cualquier cargo público según idoneidad, capacidad y rendimiento profesional. ${ }^{79}$

En España, los artículos 23.2 y 103.3 de nuestra Constitución refieren el acceso a la función pública en condiciones de igualdad así como los principios de mérito y capacidad. A diferencia del sistema alemán, no tenemos en nuestro ordenamiento jurídico un sistema de prueba que evidencie la supuesta fidelidad del futuro funcionario a la Constitución realizada con carácter previo al ingreso de los aspirantes.

Algunos autores interpretan que rige en nuestro sistema jurídico una presunción de acatamiento de la Constitución por todos los ciudadanos, de forma que únicamente ha de exigirse las pruebas que verifiquen el mérito y capacidad del artículo $103 \mathrm{y}$ respetando siempre el principio de igualdad del $23.2 \mathrm{CE}^{80}$.

Sin embargo, como sucede en el sistema alemán, nuestro Tribunal Constitucional sí ha declarado expresamente que el acceso a cargo público implica acatar expresamente la Constitución, y así ha manifestado el deber de prestar juramento y acatamiento de nuestra Carta Magna tanto por Diputados de Herri Batasuna ${ }^{81}$ como por parlamentarios gallegos $^{82}$, si bien los puntos de partida de sendos procedimientos eran diferentes.

77 BVerfGE 39, 334, Segunda Sala, 22 de mayo de 1975. BvL 13/73.

78 Der «Radikalenerlass» von 1972 und seine Folgen. «Solo aquellos que ofrecen la garantía de defender el orden básico democrático libre en el sentido de la Ley Básica pueden ser nombrados para la relación de servicio civil».

79 BverfGE 108, 282, de 24 de septiembre de 2003, relativa al Velo islámico.

80 Embid Irujo, A., op. cit., pág. 165.

81 STC 101/1983, de 18 de noviembre, fundamento jurídico 3.

82 STC 122/1983, de 16 de diciembre de 1983. 
Mientras en la primera sentencia, el objeto principal del recurso es la obligación de acatar la Constitución que establece el Reglamento del Congreso, en la STC 122/1983 el planteamiento fundamental da un paso más y gira además entorno a la obligada fidelidad a la Constitución y al ordenamiento jurídico ${ }^{83}$. Más allá del deber de jurar y prometer acatamiento constitucional que motivó la STC 101/1983, en el pronunciamiento del Tribunal Constitucional sobre el recurso de amparo contra la exigencia del Reglamento del Parlamento Gallego de fidelidad constitucional por los diputados electos, la cuestión recurrida no es únicamente el acatamiento, sino además una mayor exigencia de este Reglamento en cuanto a la obligación de guardar fidelidad a la Constitución y al mismo.

El argumento principal de los recurrentes es la negación de la libertad ideológica a la que conduce el juramento exigido. Por una parte, las alegaciones de su demanda se centran en la desigualdad que el juramento produce en la pérdida de derechos entre aquellos que prometen y los que en ejercicio de su libertad ideológica, se niegan.

En segundo lugar, el recurso distingue entre un deber de acatar la Constitución concentrado en el fuero externo, y no en el ámbito interior de la conciencia, y un deber de fidelidad exigido por el Reglamento del Parlamento Gallego que implica una adhesión interior de los parlamentarios gallegos a los preceptos constitucionales. Es por ello que entienden vulnerado su derecho a la libertad ideológica del artículo $16 \mathrm{CE}$.

El Tribunal Constitucional no reconoce vulneración alguna de la libertad ideológica y tampoco diferencia alguna entre deber acatamiento y deber de fidelidad a la Constitución. En su interpretación, el deber de fidelidad se confunde prácticamente con el deber de obediencia a la Constitución y al resto del ordenamiento jurídico que deriva del artículo 9.1 de la Constitución. De este modo, en el deber de acatar nuestra Carta Magna, la obligación es la misma para todos sin desigualdad alguna, y las reservas internas son irrelevantes, no existen para el Derecho porque no entra en el ámbito del pensamiento, en tanto no se manifieste en conductas externas. Igualmente, para el Tribunal, la fidelidad a la Constitución y al Estatuto de Galicia equivale a aceptar ese orden jurídico, sin impedimentos y sin prohibición alguna para representar o incluso para perseguir ideales políticos distintos a los constitucionales ${ }^{84}$. El juramento no significa una hipoteca mental ni una limitación a sus valores y convicciones, y siguiendo el mismo criterio de su sentencia 101/1983, el deber de acatamiento constitucional inherente al cargo, con independencia de que se exteriorice, no supone necesariamente adhesión ideológica ni conformidad con el contenido ${ }^{85}$.

En esta misma línea, la posterior STC 119/1990 despeja toda duda sobre la licitud constitucional de la exigencia de juramento o promesa de acatamiento, requisito no impuesto por la Constitución, sino por el artículo 108.6 de la Ley Orgánica 5/1985 y por el Congreso de los Diputados. Sin embargo, en esta sentencia el Tribunal Cons-

83 STC 122/1983, de 16 de diciembre de 1983, fundamento jurídico 5.

84 STC 122/1983, de 16 de diciembre de 1983, fundamentos jurídicos 2-5.

85 STC 101/1983, de 18 de noviembre, FJ 3.

86 Ley Orgánica 5/1985, de 19 de junio, del Régimen Electoral General.

(C) UNED. Revista de Derecho Politico

N. ${ }^{\circ} 111$, mayo-agosto 2021, págs. 225-254 
titucional realiza una laxa interpretación del deber de juramento de la Constitución, manifestando que se trata del cumplimiento o incumplimiento de un requisito formal reflejo de otros momentos culturales y de otros sistemas jurídicos ${ }^{87}$. Declara que tan legítima es, desde el punto de vista constitucional, la postura de quienes propugnan este tipo de obligaciones como la de quienes la estiman inadecuada o anacrónica, declarando asimismo, que la obligación de prestar juramento no crea un deber de sujeción a la Constitución, porque la finalidad del juramento no es la vinculación interna a la Constitución. De este modo, ni el incumplimiento de este requisito formal, ni tampoco las acciones de Diputados o Senadores incompatibles con la sumisión o el respeto a la Constitución, conducen a ninguna consecuencia, ni siquiera a la privación de la condición de Diputado o Senador ${ }^{88}$, porque en ese caso, según expone el Tribunal, se violentaría la misma Constitución y se vulnerarían los derechos fundamentales del artículo 23, haciéndose prevalecer una interpretación de la Constitución excluyente frente a otra integradora ${ }^{89}$.

Distingue sin embargo en este punto la sentencia, las consecuencias en la vulneración de derechos fundamentales para la función pública, según se trate de exigencia de acatamiento de la Constitución para cargos no representativos o se trate de representantes electos que ejercen funciones representativas. Mientras los primeros actúan sólo en nombre propio, para los segundos considera que aunque el único título válido es la elección popular. Solo a ellos podría imponerse el deber de acatar la Constitución, dado que han obtenido el voto de los electores para actuar en un sentido determinado dentro del marco constitucional ${ }^{90}$.

Respecto a la violación de los artículos 14 y 23.2 de la Constitución, si bien respecto del primero entiende el Tribunal que la fórmula de juramento es ideológicamente neutral y no adolece de discriminación alguna por razones ideológicas ${ }^{11}$, respecto de la segunda pretensión, entiende el Tribunal Constitucional que los recurrentes se han visto lesionados en el derecho que les garantiza el artículo 23.2 CE, y ello por habérseles aplicado una norma que no se exigió en otras ocasiones, lesión que trasciende también en el derecho de sus electores a participar en asuntos públicos a través de representantes.

Si bien no podríamos hablar de lealtad constitucional en el deber de prestar juramento de acatar la Constitución, pues se encuentra referido a normas cuyo objeto no se refieren a principios estructurales ${ }^{92}$, sin embargo, nuevamente en este pronunciamiento el Tribunal Constitucional vuelve a asimilar lealtad y sujeción a la Constitu-

87 STC 119/1990, de 21 de junio de 1990. FJ 7.

88 STC 119/1990, de 21 de junio de 1990. FJ 4.

89 STC 119/1990, de 21 de junio de 1990. FJ 7.

$90 \quad$ STC 119/1990, de 21 de junio de 1990. FJ 4.

91 STC 119/1990, de 21 de junio de 1990. FJ 6.

92 Álvarez Álvarez, L., La lealtad constitucional en la Constitución Española de 1978, Centro de Estudios Políticos y constitucionales, 2008, Madrid. Págs. 16. 
ción ${ }^{93}$, sin reconocer como diferencia entre ambos conceptos, la necesidad de una conformidad y adhesión ideológica a los valores constitucionales ${ }^{94}$, en este caso por los miembros de la función pública de modo que se distancia definitivamente de una concepción militante de democracia ${ }^{95}$.

Sin ánimo de exponer términos comparativos con nuestro Derecho comparado, cuestión que desbordaría los límites de esta investigación, en las normas de la LFB por ejemplo, relativas al juramento del cargo por la función pública, subyace en esencia la idea de que un Estado ha de poder confiar en sus funcionarios en el ámbito de la defensa de la Constitución, de modo que el juramento es el instrumento que fortalece esa expectativa de la ley sobre la fidelidad del funcionario a la Constitución y al Estado. Solo puede ser funcionario quien ofrece garantía de que defenderá en todo momento el orden fundamental libre y democrático conforme a la Ley Fundamental ${ }^{96}$. Funcionario y Estado están unidos por una relación recíproca de fidelidad, sin que ni siquiera en el ámbito docente, por ejemplo, la libertad de cátedra suponga una excepción a ese deber de fidelidad ${ }^{97}$ (artículo 5.3 LFB $^{98}$ ).

No es suficiente el respeto al texto constitucional de la democracia procedimental, y no son válidas ni aceptables las actitudes que aunque democráticas en las formas, esconden fines contrarios a los principios constitucionales fruto del pacto constitucional. No pueden darse por válidos los medios cuando los fines son contrarios. Cuando estos buscan destruir el sistema. La democracia ha de defenderse frente a los ataques de sus enemigos, y la función pública y los poderes del Estado deberían ser los primeros en entender y propugnar el carácter militante de toda democracia.

\section{LA FIDELIDAD A LOS VALORES CONSTITUCIONALES COMO LIMITE AL EJERCICIO DE DERECHOS FUNDAMENTALES}

Es cierto que existe un importante control ejercido por parte del Estado alemán en la ideología democrática o constitucional ${ }^{99}$ y se manifiesta de una forma muy clara en un deber de fidelidad exigido a los funcionarios públicos, fidelidad tanto a la Constitución como al Estado, y deber sobre el que la jurisprudencia del Tribunal Constitucional alemán se ha pronunciado como deber de mantenerse al margen de

93 STC 122/1983, de 16 de diciembre de 1983, FJ 5.

94 STC 101/1983, de 18 de noviembre, FJ 3.

95 Sentencia del Tribunal Constitucional 48/2003, de 12 de marzo (BOE núm. 63, de 14 de marzo de 2003) FJ 7. Esta misma idea es sostenida también posteriormente por el Tribunal Constitucional en su sentencia STC 5/2004, citada, FJ 17, negando el carácter militante de nuestra democracia.

96 Como ya establecía el Decreto Anti-radical sobre Extremistas, de 28 de enero de 1972.

97 Denninger, E., op. cit., pág. 456 - 458.

98 Artículo 5.3 Ley Fundamental de Bonn. Ley para la República Federal de Alemania (Grundgesetz für die Bundesrepublik Deutschland), de 22 de mayo de 1949. «El arte y la ciencia, la investigación y la enseñanza científica son libres. La libertad de enseñanza no exime de la lealtad a la Constitución».

99 Blat Jimeno, Francisco R., op. cit., pág. 75.

N. o 111, mayo-agosto 2021, págs. 225-254 
grupos contrarios a la Constitución. El Tribunal alemán ha desarrollado este concepto en que la obligación de lealtad política exige algo más que un comportamiento formalmente correcto, superficialmente distanciado frente al Estado y la Constitución. Exige del funcionario en particular, que se distancie claramente de los grupos y tentativas que atacan, difaman y combaten los órganos constitucionales y el vigente ordenamiento de la Constitución. Del funcionario se espera que conozca y reconozca este Estado y su Constitución como un alto valor positivo que vale la pena defender ${ }^{100}$. El deber de fidelidad público alemán exige por tanto, una conducta positiva por parte del funcionario de defensa de la Constitución y el Estado alemanes en sus aspectos esenciales, conducta que no se considera adecuada con el solo respeto a los valores fundamentales de la Constitución y el Estado, sino que necesariamente ha de conducir al funcionario alemán a una manifestación externa de su adhesión ideológica a esos principios y valores constitucionales. Exige que el individuo llegue a implicarse activamente en la defensa del Estado y de la Constitución.

No obstante, es preciso señalar que estamos ante una relación jurídica personal en que la Constitución confía ciertas tareas a la función pública ${ }^{101}$. Una concepción de la relación funcionarial como relación de especial sujeción que otorge preferencia absoluta a los intereses generales, conduciría necesariamente a la restricción automática de los derechos fundamentales.

En el caso concreto de nuestro ordenamiento jurídico, el concepto de Estado democrático y de Derecho y la vinculación de los poderes públicos al respeto a los derechos fundamentales de acuerdo a los artículos 9.1 y 1.1 de nuestra Constitución, conduce a la consideración de los derechos fundamentales como instrumento de protección y garantía frente a las intervenciones del Estado y ello, si bien es cierto que tampoco pueda aceptarse que el ejercicio de los mismos pueda llegar a obstaculizar el cumplimiento del interés general por parte de los integrantes de la Administración. En consecuencia, las restricciones de derechos solo podrán justificarse por la especial vinculación del funcionario al interés general y al servicio público que desempeña. De este modo, el sometimiento de la Administración y la función pública a la ley y al Derecho según el 103.1 CE podría llegar a justificar la restricción de derechos en determinados $\operatorname{casos}^{102}$.

Cabría plantearse por tanto, si en el caso español al funcionario público se le exige una actuación concreta encaminada a esa defensa constitucional. O si por el contrario, basta y es suficiente con la mera omisión de comportamientos en contra del ordena-

100 BVerfGE 39, 448 y 39,334.

101 Stern, K., op. cit., pág. 376, 385, 616-618 y 632-644.

102 Para profundizar en todo este tema, que por motivos de espacio excedería los límites de este estudio, pueden consultarse diversos autores. Entre otros, García de Enterría, E., «Hacia una nueva justicia administrativa» Revista española de derecho administrativo, $\mathrm{n}^{\circ} 75$, Civitas. Madrid, 1992. Jellinek W., Venvaltungsrecht, 1966. Schnapp, F. E., Amtsrecht und Beamtenrecht: eine Untersuchung uber normative Strukturen des staatlichen Innenbereichs, 1977. Benda, E., Maihofer, W., Vogel, H., Hesse, K., Heyde, W., Manual de Derecho Constitucional. Editorial Marcial Pons. Madrid, 1996. 
miento jurídico constitucional establecido. Y es el propio Tribunal Constitucional, como máximo interprete y órgano encargado de la defensa constitucional, quien en las sentencias ya analizadas nos adelanta respuesta a esta cuestión, aludiendo en sus referidos pronunciamientos a una doble dimensión de la libertad ideológica ${ }^{103}$. Una dimensión interna o «singular ética privada» del individuo en que como ámbito íntimo de la conciencia no puede interferir el Derecho, y una dimensión externa exteriorizada y susceptible de control. Interpreta el artículo 9 de la Constitución como un deber de respeto que no requiere ni la adhesión ideológica interna ni la conformidad al texto constitucional. ${ }^{104} \mathrm{La}$ exigencia de nuestro Tribunal Constitucional se concreta por tanto, en el acatamiento de los principios y valores de nuestra Constitución y nuestro ordenamiento jurídico como actitud exteriorizada, meramente formal, sin que ello pueda interpretarse como concepto estricto de fidelidad del funcionario y adhesión interior de conciencia e identidad con esos principios y valores constitucionales. Aunque los fines últimos perseguidos sean contrarios, la omisión de conductas contrarias y reiteradas contra la Constitución, si cumplen con el principio de neutralidad política, es valorada como suficiente, llegando incluso a reconocer en sus declaraciones la falta de consecuencias en caso contrario. Se admite una actitud neutral meramente formal, en que los fines perseguidos como hemos analizado, no tienen gran trascendencia.

No existe por tanto, en nuestro ordenamiento jurídico ni a la vista de nuestra jurisprudencia, obligación alguna para la función pública de una defensa militante de nuestra Constitución ${ }^{105}$ ni obligación de adhesión ideológica a los preceptos constitucionales.

Entra aquí en juego entonces, en la vertiente personal, la imparcialidad del empleado público en el ejercicio de sus funciones. Aunque nuestro ordenamiento jurídico no acoja un sistema de ideología del Estado equivalente al ordenamiento jurídico alemán ${ }^{106}$, y nuestra Constitución en principio, pueda parecer en principio y a primera vista, que no adopte un modelo de «Democracia Militante» ${ }^{107}$, que imponga la adhesión positiva al ordenamiento y a la Constitución como sucede en el sistema

103 Aparicio Tovar, J., «Relación de trabajo y libertad de pensamiento en las empresas ideológicas», en VV.AA., en Lecciones de Derecho del Trabajo en homenaje a los profesores Bayón Chacón y del Peso y Calvo. Facultad de Derecho. Universidad Complutense de Madrid, 1980, Madrid. Pág. 276. También Valero Heredia, A., op. cit., pág. 63 - 74.

104 STC 101/1983, de 18 de noviembre, fundamento jurídico 3. STC 119/1990, de 21 de junio de 1990. STC 122/1983, de 16 de diciembre de 1983, FJ 5.

105 Embid Irujo, A., op. cit., pág. 168

106 Blat Jimeno, Francisco R., op. cit., pág. 76.

107 Sobre esta cuestión, puede consultarse a Torres del Moral, A., «Democracia militante», en Carrasco Durán, M.; Pérez Royo, J.; Urías Martínez, J.; Terol Becerra, M.J.; Derecho constitucional para el siglo XXI: actas del VIII Congreso Iberoamericano de Derecho Constitucional, Vol. 1, 2006, págs. 209-224; También Revenga Sánchez, M., «El tránsito hacia (y la lucha por) la Democracia Militante en España», en Revista de derecho político, 62, 2005, págs. 11-31.

N. ${ }^{\circ} 111$, mayo-agosto 2021, págs. 225-254 
alemán ${ }^{108}$, en un Estado de Derecho, la actuación profesional en la función pública debe estar siempre encuadrada en el seno de una Administración sometida a la Constitución y al resto del ordenamiento jurídico. En definitiva, sólo pueden tener lugar dentro del marco constitucional ${ }^{109}$.

De este modo, determinados preceptos de nuestro ordenamiento jurídico manifiestan de forma clara el carácter militante de toda democracia ante la coherente necesidad de defensa de sus propios valores constitucionales. Nos referimos en concreto a ciertos artículos como el artículo 26 de la Ley 19/2013 de transparencia ${ }^{110}$ o el artículo 55 de la Ley 19/2014 del Parlamento de Cataluña sobre Buen gobierno ${ }^{111}$ cuando establecen expresamente un servicio público en el marco constitucional y en el respeto a los derechos fundamentales, excluyendo expresamente los ataques a la Constitución o los valores constitucionales bajo la consideración como infracción muy grave y disciplinaria del incumplimiento de este deber.

En el ordenamiento jurídico español, la actuación del funcionario está vinculada al principio de neutralidad e imparcialidad y al de objetividad de la Administración Pública. Así lo manifiesta el artículo 52 del Estatuto Básico del Empleado Público cuando en el Código de Conducta establece que deberán velar por los intereses generales con sujeción y observancia de la Constitución y del resto del ordenamiento jurídico actuando de acuerdo a principios de objetividad, integridad, neutralidad, responsabilidad, imparcialidad, e igualmente en el artículo 53.2 cuando menciona entre los principios éticos que han de regir la actuación del funcionario, la satisfacción de los intereses generales de los ciudadanos y se fundamentará en consideraciones objetivas orientadas a la imparcialidad y el interés común, al margen de cualquier otro factor que exprese posiciones personales, familiares, corporativas, clientelares o cualesquiera otras que puedan colisionar con este principio ${ }^{112}$. La previsión expresa del deber de respeto a la Constitución de los artículos 52 y 53.1 del EBEP (con la consiguiente calificación en el artículo 95.a como falta disciplinaria muy grave la omisión o incumplimiento de este deber), así como la obligación de imparcialidad en el ejercicio de sus funciones (artículo 103.1 y 3 CE), conducen a exigir un comportamiento objetivo en la función pública ${ }^{113}$, que de acuerdo con el 53.2 EBEP, ha de estar encaminado a la satisfacción del interés general y basado en el principio de imparcialidad, siempre con independencia de otras intenciones o circunstancias que puedan colisionar con este principio.

108 Sanz Moreno, J.A., op. cit., pág. 623.

109 Arias Martínez, M. A., op. cit., pág. 192 - 193.

110 Ley 19/2013, de 9 de diciembre, de transparencia, acceso a la información pública y buen gobierno. BOE núm. 295, de 10 de diciembre de 2013.

111 Ley 19/2014, de 29 de diciembre, de transparencia, acceso a la información pública y buen gobierno. Comunidad Autónoma de Cataluña. DOGC núm. 6780, de 31 de diciembre de 2014. BOE núm. 18, de 21 de enero de 2015.

112 Artículo 52 y 53, Capítulo VI, Real Decreto Legislativo 5/2015, de 30 de octubre, por el que se aprueba el texto refundido de la Ley del Estatuto Básico del Empleado Público.

113 Arias Martínez, M. A., op. cit., pág. 192 - 193. 
En esta línea, el artículo 103.3 de la Constitución de 1978 recoge, además de los principios de mérito y capacidad para el acceso a la Función Pública, el de imparcialidad en el ejercicio de las funciones, principio estrechamente vinculado al principio de objetividad y neutralidad en los funcionarios públicos, aludiendo el principio de objetividad a la Administración y los otros dos principios a las actuaciones del personal a su servicio ${ }^{114}$.

Así lo manifiesta el artículo 20.2 del Estatuto Básico del Empleado Público cuando establece que los sistemas de evaluación del desempeño se adecuarán, en todo caso, a criterios de transparencia, objetividad, imparcialidad y no discriminación y se aplicarán sin menoscabo de los derechos de los empleados públicos ${ }^{115}$.

En este sentido, la objetividad de la Administración se convierte en una consecuencia de la imparcialidad de la actuación de los funcionarios que la integran, produciéndose una relación causa-efecto entre objetividad e imparcialidad. De este modo, cuando la autoridad o funcionario actúa con imparcialidad, el resultado es la objetividad de la Administración ${ }^{116}$.

No podemos hablar por tanto, de una obligación o deber español de estricta fidelidad, si bien algunos autores así lo valoran aunque con una exigencia limitada al tiempo y lugar del cumplimiento de las funciones del cargo en el ejercicio de la función pública. ${ }^{117} \mathrm{El}$ deber de respeto y acatamiento constitucional vincula al funcionario únicamente durante la actividad desarrollada en ejercicio de la función pública, si bien en la medida en que la condición de funcionario debería implicar una adhesión ideológica interior a los principios y valores constitucionales, sí debería vincular su defensa y una actitud activa y positiva dentro y fuera del lugar de trabajo, y dentro y fuera del horario laboral. La cuestión no es el momento o el lugar, sino la condición de funcionario público que, aunque no desempeñe funciones representativas, por tratarse del ejercicio de una función pública y la defensa de unos intereses generales, no debería limitarse a lugares y tiempos de trabajo. La protección frente a un atentado al núcleo de la Constitución es una cuestión que involucra a todo el Estado constitucional, a sus instituciones, y muy especialmente a los titulares de cargos públicos que deben custodia y protección a la Constitución y al Derecho de una forma especial, como solemne deber personal manifiesto en el acto del juramento. El funcionariado es indispensable para el Estado administrativo moderno, no solo desde la perspectiva del Estado y sus funciones, sino también desde el punto de vista del ciudadano y sus expectativas de que la justicia, libertad y eficacia estén garantizados por el Estado. De un funcionario que fuera de su cargo, se dedica a un partido, no se puede esperar ser considerado neutral en su cargo porque como relación jurídica personal, no admite

114 Arias Martínez, M. A., ibídem, pág. 186, 192, 195.

115 Real Decreto Legislativo 5/2015, de 30 de octubre, por el que se aprueba el texto refundido de la Ley del Estatuto Básico del Empleado Público.

116 Morell Ocaña, L., «La objetividad de la Administración Pública y otros componentes de la ética de la institución», REDA , n. ${ }^{\circ}$ 111, 2001. Pág. 363.

117 Embid Irujo, A., op. cit., pág. 79 y 167.

(C) UNED. Revista de Derecho Politico

N. o 111, mayo-agosto 2021, págs. 225-254 
una esfera privada y la escisión entre la esfera del cargo y la esfera externa del mis$\mathrm{mo}^{118}$. Su fidelidad a la Constitución es un deber en todo tiempo y todo lugar, dentro y fuera del servicio. Ya el Decreto alemán de 1972 refería que los funcionarios trabajen activamente dentro y fuera del servicio para mantener este orden básico, ${ }^{119} \mathrm{y}$ de la misma forma que se prohíben partidos políticos cuyo fines sean contrarios a la LFB, se llegó incluso a restringir el acceso a la función pública para aquellos aspirantes radicales, que en su momento, realizaban actividades contrarias a la Constitución.

Podríamos entonces plantearnos hasta qué punto es legitima la actuación del funcionario que, siguiendo su obligación de imparcialidad, se limita a seguir las instrucciones del gobierno de turno ${ }^{120}$. Realmente, es la necesidad de otorgar efectividad a la libertad de conciencia el factor que compromete la posición jurídica del Estado. Por una parte, en la vertiente negativa de neutralidad estatal, el Estado, como garante negativo de derechos fundamentales, se encuentra sometido a un deber de no intromisión en el ámbito de las convicciones del individuo y obligado a no impedir tanto su ejercicio como su libre desarrollo. Por otra parte, en la vertiente positiva del principio de neutralidad estatal, como titular de obligaciones positivas asumidas por los poderes públicos, el Estado se encuentra obligado a facilitar un ejercicio real de los derechos de libertad ${ }^{121}$. La previsión expresa del deber de respeto a la Constitución de los diversos preceptos de nuestro ordenamiento sería suficiente para exigir al funcionario público un comportamiento objetivo en sus funciones ${ }^{122}$, si bien más allá, un comportamiento en contra de la obligación de imparcialidad del empleado público en el ejercicio de sus funciones (artículo 103.1 y 3 CE), supondría una vulneración de la obligación contenida en los artículos 52 y 53.1 del EBEP ${ }^{123}$. En caso de incumplimiento de esta obligación, tanto el artículo 95.a) ${ }^{124}$ como el artículo 29 de la Ley 19/2014 del Parlamento de Cataluña sobre Buen gobierno ${ }^{125}$, disponen la calificación expresa como falta disciplinaria muy grave, el supuesto de incumplimiento del deber de respeto a la Constitución y a los respectivos Estatutos de Autonomía de las Comunidades Autónomas en el ejercicio de la función pública. En la idea de protección de los titulares de funciones públicas ante influencias externas, pueden divisarse tipos penales, constitucionales y además sanciones disciplinarias. El funcionario debe responder personalmente de su conducta oficial si bien también es titular del derecho a

118 Stern, K., op. cit., pág. 376, 385 y 632 - 644.

119 Der «Radikalenerlass» von 1972 und seine Folgen.

120 Álvarez Álvarez, J., op. cit., pág. 74.

121 Valero Heredia, A., op. cit., pág. 111 - 117.

122 Arias Martínez, M. A., op. cit., pág. 192 - 193.

123 Real Decreto Legislativo 5/2015, de 30 de octubre, por el que se aprueba el texto refundido de la Ley del Estatuto Básico del Empleado Público.

124 Artículo 95.a), Capítulo VI, Real Decreto Legislativo 5/2015, de 30 de octubre, por el que se aprueba el texto refundido de la Ley del Estatuto Básico del Empleado Público.

125 Ley 19/2014, de 29 de diciembre, de transparencia, acceso a la información pública y buen gobierno. Comunidad Autónoma de Cataluña. DOGC núm. 6780, de 31 de diciembre de 2014. BOE núm. 18, de 21 de enero de 2015. 
defenderse cuando se le impute una conducta irregular, debiendo examinarse la constitucionalidad de su actuación oficial. ${ }^{126}$

La democracia militante ha sido duramente criticada como concepto vinculado a la limitación de estos derechos fundamentales ${ }^{127}$. Entra aquí en juego la concepción de los derechos fundamentales como derechos subjetivos y su carácter de preceptos negativos de competencia, que en cuanto defensa del individuo frente a las intervenciones injustificadas del Estado, marcan el límite de las competencias estatales tanto legislativas, administrativas como judiciales, excluyendo de esa competencia estatal el ámbito que protegen y operando como límite a la acción estatal, tanto en las relaciones de los individuos con los poderes públicos, como en las relaciones entre particulares. De esta vinculación de los poderes legislativo, ejecutivo y judicial a los derechos fundamentales deriva no solo la obligación negativa del Estado de abstenerse de injerencias en el ámbito protegido por estos derechos fundamentales, sino también una obligación positiva de realizar todo aquello que conduzca a la realización de los derechos fundamentales ${ }^{128}$. Y conviene señalar entonces, en este punto que la única posible justificación para la adopción de medidas limitativas o restrictivas de derechos fundamentales es la existencia de una necesidad pública superior ${ }^{129}$. En el concepto formal de función pública, el factor determinante es la actividad al servicio de una persona jurídica de Derecho público y adicionalmente, hay que considerar una serie de características frente a las relaciones de servicio jurídico privadas. Principalmente, estamos ante una relación de servicio y lealtad, que implica una serie de derechos y obligaciones y que además se fundamenta en el nombramiento ${ }^{130}$. En esta línea, el Tribunal Constitucional Federal reconoce la restricción de derechos únicamente para casos concretos y especialmente ante peligros abstractos de la paz comunitaria ${ }^{131} \mathrm{y}$ rechaza cualquier protección restringida «ipso iure» de los derechos fundamentales, cuando niega la subordinación del funcionario al puesto estatal así como su renuncia a sus derechos de libertad individual ${ }^{132}$. La LFB como democracia vinculada a valores y dispuesta a defenderlos frente a los enemigos de la Constitución, contiene unos principios básicos del Estado que valorados como principios absolutos, han de ser defendidos frente a cualquier ataque e incluso si fuese necesario, llegando a limitar la libertad de actuación de estos enemigos, y ello si bien puede llegar a ser complicado justificar la intromisión en un derecho fundamental ante un peligro abstracto, no concreto, debiendo acudirse, en su caso al criterio de proporcionalidad y siempre, bajo

126 Stern, K., op. cit., pág. 377.

127 Stern, K., ibídem, pág. 390

128 Hesse, C., «Significado de los derechos fundamentales» en Benda, E., Maihofer, W., Vogel, H., Hesse, K., Heyde, W., Manual de Derecho Constitucional. Editorial Marcial Pons. Madrid, 1996. Pág. $91-94$.

129 Frings, D., op. cit., pág. 176-178.

130 Stern, K., op. cit., pág. 603 - 606.

131 Sentencia del Tribunal Constitucional alemán de 24 septiembre de 2003 - 2 BvR 1436/02.

132 Sentencia del Tribunal Constitucional Federal del 24 septiembre de 2003 - 2BvR 1436/02.

(C) UNED. Revista de Derecho Politico

N. o 111, mayo-agosto 2021, págs. 225-254 
un análisis particular e individualizado y protegiendo al individuo de las intromisiones excesivas o intensas. En un intento de protección de la Constitución frente a sus enemigos, el artículo 18 LFB se refiere a la privación de ciertos derechos fundamentales para aquellos que para combatir el régimen fundamental de libertad y democracia, abusen de la libertad de expresión, opinión, libertad de prensa, la libertad de enseñanza, de reunión, de asociación, del secreto de las comunicaciones postales y de las telecomunicaciones, así como del derecho de propiedad y del de asilo. Para que se produzca esa pérdida de derechos fundamentales se hace precisa la existencia de un ataque contra el orden fundamental liberal democrático mediante el uso de determinados derechos fundamentales de modo abusivo, entendiendo aquí como abusivo un uso de derechos fundamentales contra el orden fundamental liberal democrático. La consecuencia es la declaración de pérdida del derecho, competencia del Tribunal Constitucional Federal, de modo que el afectado no podrá invocar esos derechos fundamentales de los que ha sido privado, y deberá aceptar las intervenciones del poder público. Las restricciones en el status jurídico del afectado se concretan en una intervención estatal compatible con el principio de proporcionalidad como prohibición de exceso, y limitación de la medida ${ }^{133}$. Para que se llegue a producirse una separación del servicio no basta con cualquier falta de fidelidad debida, cuando el funcionario no se identifica con el orden democrático de la Ley Fundamental, siendo necesario llegar a una actuación más intensa, se requiere «un atentado contra las propias obligaciones», de modo que sean deducibles consecuencias en su actitud respecto del orden constitucional y respecto de la forma de cumplir sus obligaciones de servicio ${ }^{134}$.

Si bien en este ámbito pueden encontrarse otros muchos y diversos planteamientos de la doctrina administrativista por los que cabría plantearse otro tipo de cuestiones más específicas, abordar todos estos extremos desbordaría los límites marcados en esta obra.

\section{CONCLUSIONES}

A pesar de las connotaciones negativas que pueda haber ido adquiriendo el concepto heredado de «democracia militante», solo tenemos que volver la vista atrás hacia la experiencia histórica alemana, quizás la más grave en este ámbito en nuestro Derecho comparado, para ver en la derrota de la democracia de Weimar como una democracia que no defiende y propugna sus valores y principios constitucionales es cuestión de tiempo su decadencia. No cabe entender un Estado democrático indiferente. Que no proteja y defienda sus propios valores que compartidos por la mayoría de los ciudadanos, además de identificarle, constituyen su propia ética de Estado, su orden, sus reglas de convivencia y su esencia como nación justa, democrática, y libre.

133 Stern, K., op. cit., pág. 387 y $396-399$

134 BVerf-GE 39,351. Denninger, E., op. cit., pág. 479 - 480. 
Estos valores han de ser necesariamente protegidos por todas las instituciones y órganos del Estado, por la función pública, así como como por los distintos partidos políticos que tienen cabida en un Estado Democrático en que el pluralismo ideológico necesariamente ha de estar está limitado por el respeto y defensa de esos valores y principios constitucionales. Porque no cabe toda opción, en la medida en que tanto las instituciones y poderes del Estado como la función pública han de estar sometidos al Derecho. Porque tanto los partidos como las instituciones, los poderes y los órganos del Estado están al servicio de la Constitución. No viceversa.

La defensa de la Constitución más allá de conducirnos a la ilicitud de todos aquellos fines contrarios a las normas constitucionales, aun cuando los procedimientos utilizados en su persecución sean democráticos, debe conducirnos además a que esa defensa constitucional se refleje en la promoción de un orden justo y en libertad, y no solo derivado de la premisa básica de la división de poderes, sino además suscitado y defendido activamente por todas las instituciones y poderes del Estado y Administración Pública, que como instrumentos al servicio de los ciudadanos, se encuentran sometidos al Derecho y al orden constitucional. No es suficiente el respeto al texto constitucional de la democracia procedimental, y no son válidas ni aceptables las actitudes que aunque democráticas en las formas, esconden fines contrarios a los principios constitucionales fruto del pacto constitucional. No pueden darse por válidos los medios cuando los fines son contrarios. Cuando estos buscan destruir el sistema. Enemigos de la Constitución son quienes persiguen fines contrarios a ella, y atendiendo a la lealtad constitucional desde una perspectiva de norma de defensa del Estado, inevitablemente deviene la ilegalización de los enemigos de la Constitución, de quienes persiguen fines contrarios a sus principios estructurales.

Toda democracia ha de entenderse como militante porque necesariamente ha de defenderse frente a los ataques de sus enemigos, y no cabe entender una democracia indiferente en la defensa de sus valores constitucionales. La función pública y los poderes del Estado deben ser los primeros en entender y propugnar el carácter militante que es inherente al concepto de democracia.

Todo Estado ha de poder confiar en sus funcionarios en el ámbito de la defensa de la Constitución, y el juramento es el instrumento que fortalece esa expectativa. Si bien el deber de neutralidad funcionarial en el ordenamiento jurídico español se articula de acuerdo a las exigencias de un modelo procedimental de democracia, debería configurarse según los requerimientos de una democracia militante, que duramente criticada por entenderse vinculada a la limitación de derechos fundamentales, plantea la actividad funcionarial como una relación jurídica personal en que no puede desligarse la esfera privada de la esfera del cargo al servicio de una persona de Derecho público, valorando la restricción de derechos bajo criterios de proporcionalidad y solo y únicamente para aquellos casos en que el abuso del derecho fundamental derive en un ataque contra los principios básicos del Estado. 
Title

Constitutional values and principles as limits on the actions of State powers and the Public service.

\section{Summary.}

INTRODUCTION. I. LOYALTY TO THE CONSTITUTIONAL VALUES AND THE ILLEGALNESS OF THE CONTRARY PURPOSES. II. THE INSTRUMENTAL CHARACTER OF THE PUBLIC ADMINISTRATION AND THE LIMITS ON ITS PERFORMANCE. III. THE OATH. INTERNAL ADHESION TO THE CONSTITUTIONAL VALUES IN ACCESS TO POSITION. IV. FIDELITY TO THE CONSTITUTIONAL VALUES AS A LIMIT TO THE EXERCISE OF FUNDAMENTAL RIGHTS. V. CONCLUSIONS.

\section{Resumen}

El éxito de la Constitución de cualquier Estado reside, más allá de su legalidad como norma escrita, tanto en el grado de adhesión de sus ciudadanos, como en qué medida sus instituciones y función pública promueven y defienden la legitimidad de sus principios y valores constitucionales, fruto del pacto constitucional en el que ese mismo pueblo como verdadero poder constituyente, ha ejercido su soberanía.

La Constitución y el bloque constitucional desempeñan la función normativa de lealtad constitucional bajo el presupuesto de su supremacía. Si el derecho pretende ser válido y no quedar relegado a una mera construcción ideal, debe buscar la eficacia generalizada del ordenamiento jurídico mediante la lealtad constitucional de todas las instituciones y funcionarios públicos a los principios estructurales de nuestra Carta Magna.

La previsión expresa del artículo 168 CE de posible revisión total de su texto, sin existir cláusula alguna de intangibilidad, conducen tanto al Tribunal Constitucional como al Tribunal Supremo a la negación del carácter militante de nuestra democracia, interpretando el 9.1 como un deber de lealtad constitucional equiparable a la sujeción, sin hallar diferencia alguna entre deber acatamiento y deber de fidelidad a la Constitución y ello ni aún en el propio acto del juramento a nuestra Carta Magna, dado que considerando que carece de significado alguno de sujeción a la Constitución, en la finalidad de dicho juramento no estaría contemplada la vinculación interna a la Constitución. De este modo, el acatamiento de los principios y valores de nuestra Constitución y nuestro ordenamiento jurídico es considerado como una simple actitud exterior meramente formal, sin que lamentablemente pueda interpretarse como concepto estricto de fidelidad del funcionario y adhesión interna de conciencia e identidad con esos principios y valores constitucionales. El reconocimiento de nuestra democracia como procedimental abre la puerta a todas las ideas y todos los programas políticos como legítimos, con el único requisito de métodos 
democráticos, y ello aún buscando perseguir fines contrarios a los valores básicos del constitucionalismo.

En este contexto, el planteamiento sobre la legitimidad de la actuación del funcionario bajo instrucciones del gobierno de turno, conduce a la necesaria existencia de una necesidad pública superior y una actividad de servicio. El funcionariado es indispensable para el Estado administrativo moderno, no solo desde la perspectiva del Estado y sus funciones, sino también desde el punto de vista del ciudadano y sus expectativas de que la justicia, libertad y eficacia estén garantizados por el Estado. La neutralidad positiva encomienda a los poderes y a la función pública a adoptar una postura activa en la defensa y promoción del ideario constitucional y los valores democráticos que definen el Estado constitucional y frente a ellos, ni la Administración ni la función pública pueden permanecer indiferentes. Ni la objetividad ni la imparcialidad justifican la insuficiente defensa de nuestros valores constitucionales.

\begin{abstract}
The success of the Constitution of any State resides, beyond its legality as a written norm, both in the degree of adherence of its citizens, and to what extent its institutions and public function promote and defend the legitimacy of its constitutional principles and values, fruit of the constitutional pact in which the people as a true constituent power, exercises its sovereignty.

The Constitution and the constitutional bloc perform the normative function of constitutional loyalty under the presupposition of their supremacy. If the law is intended to be valid and not be relegated to a mere ideal construction, it must seek the general effectiveness of the legal system through the constitutional loyalty of all public institutions and officials to the structural principles of our Magna Carta.

The possible total revision of the constitutional text, as article $168 \mathrm{CE}$ says, without any intangibility clause, leads both the Constitutional Court and the Supreme Court to deny the militant character of our democracy, interpreting 9.1 as a constitutional duty of loyalty comparable to subjection, without finding any difference between the duty of compliance and the duty of fidelity to the Constitution nor even in the act of the oath to our Magna Carta, without any meaning of submission to the Constitution, because the purpose of the oath is not internal link to the Constitution. Compliance with the principles and values of our Constitution and our legal system is only a merely formal external attitude, without it being interpreted as a strict concept of official fidelity and internal adherence of conscience and identity with those constitutional principles and values. Its recognition of our democracy as procedural opens the door to all ideas and all political programs as legitimate, with the only requirement of democratic methods, even those against the basic values of constitutionalism.
\end{abstract}


In this context, the approach to the legitimacy of the action of the official under instructions from the government of the day leads to the existence of a higher public need and a service activity. The civil service is indispensable for the modern administrative State, not only from the perspective of the State and its functions, but also from the point of view of the citizen and his expectations that justice, freedom and efficiency are guaranteed by the State. Positive neutrality entrusts the public function to adopt an active posture in the defense and promotion of the constitutional ideology and the democratic values that define the constitutional State and so, neither the Administration nor the public function can remain indifferent. Neither objectivity nor impartiality justify the insufficient defense of our constitutional values.

\section{Palabras clave}

valores; democracia; partidos politicos; reforma constitucional; poderes públicos.

\section{Key words}

Values, democracy; political parties; constitutional reform; public powers. 